African Crop Science Journal by African Crop Science Society is licensed under a Creative Commons Attribution 3.0 Uganda License. Based on a work at www.ajol.info/ and www.bioline.org.br/cs DOI: https://dx.doi.org/10.4314/acsj.v27i3.3

\title{
YIELD STABILITY IN SMALL RED INTER-RACIAL COMMON BEAN LINES IN KENYA
}

\author{
J.M. MONDO ${ }^{1,2}$, P.M. KIMANI ${ }^{1}$ and R.D. NARLA ${ }^{1}$
}

${ }^{1}$ Department of Plant Science and Crop Protection, University of Nairobi, P. O. Box 29053-00625, Nairobi, Kenya

${ }^{2}$ Faculty of Agriculture and Environmental Sciences, Université Evangélique en Afrique (UEA), P. O. Box 3323, Bukavu, Democratic Republic of Congo

Corresponding author: mondo.mubalama@yahoo.fr,mondo.mubalama@uea.ac.cd

(Received 24 January 2019; accepted 22 July 2019)

\begin{abstract}
Agronomic performance of new common bean (Phaseolus vulgaris L.) varieties may vary considerably in diverse agro-ecological zones, due to genotype-environment $(\mathrm{G} \times \mathrm{E})$ interactions. A multi-site evaluation is, therefore, crucial in elite lines selection as it considers simultaneously both yield and stability of performance, making selection of genotypes more precise and refined. This study aimed at assessing the agronomic performance and yield stability of $24 \mathrm{~F}_{1.7}$ small red bean lines, selected for multiple disease resistance, using molecular markers from 16 inter-racial bean populations. The study lines were evaluated in low, medium and high altitude agro-ecological conditions in Kenya. G x E effects for grain yield were highly significant $(\mathrm{P}<0.001)$, implying that the agronomic potential of the small red bean lines varied with agro-ecological zones. Tigoni, the high altitude $(2130 \mathrm{~m}$ above sea level) test site had the highest grain yield $\left(3,809 \mathrm{~kg} \mathrm{ha}^{-1}\right)$. There were no significant differences between medium altitude (1820 masl) Kabete (1,100 $\left.\mathrm{kg} \mathrm{ha}^{-1}\right)$ and low altitude (1150 masl) Mwea (1,025 $\left.\mathrm{kg} \mathrm{ha}^{-1}\right)$ sites. Number of pods per plant was strongly positively correlated with seed yield $\left(\mathrm{r}=0.85^{* * *}\right)$, and could be adopted by breeders as an indirect selection method for grain yield. The $\mathrm{G} x$ E interaction on grain yield was high (14.4\%), implying that most of genotypes should be selected and recommended to specific environments. The high yielding line, KMA13-25-09 $\left(3,385 \mathrm{~kg} \mathrm{ha}^{-1}\right)$, was the least stable across sites. Disease severity score for target diseases was low to intermediate regardless of the genotypes and sites.
\end{abstract}

Key Words: Disease resistance, Phaseolus vulgaris, severity

\section{RÉSUMÉ}

Les performances agronomiques des nouvelles variétés de haricot commun (Phaseolus vulgaris L.) peuvent varier considérablement dans diverses zones agro-écologiques, en raison des interactions génotype-environnement ( $\mathrm{G}$ x E). Une évaluation multi-site est donc cruciale pour la sélection des lignées d'élite, car elle prend en compte simultanément le rendement et la stabilité des performances, 
rendant la sélection des génotypes plus précise et affinée. Cette étude visait à évaluer les performances agronomiques et la stabilité au rendement de 24 lignées de haricots rouges F1.7, sélectionnées pour leur résistance à de multiples maladies, à l'aide de marqueurs moléculaires provenant de 16 populations de haricots interraciaux. Les lignées étudiées ont été évaluées dans des conditions agro-écologiques d'altitude basse, moyenne et haute au Kenya. Les effets de $\mathrm{G} \times \mathrm{E}$ sur le rendement en grain étaient très significatifs $(\mathrm{P}<0,001)$, ce qui impliquait que le potentiel agronomique des petites lignées de haricots rouges variait selon les zones agro-écologiques. Tigoni, le site d'essai à haute altitude $(2130 \mathrm{~m} \mathrm{au}$ dessus du niveau de la mer), a eu le rendement grainier le plus élevé (3 $809 \mathrm{~kg}$ ha-1). Il n'y avait pas de différences significatives entre les sites de moyenne altitude (1820 $\mathrm{m}$ au dessus du niveau de la mer) de Kabete (1 $100 \mathrm{~kg}$ ha-1) et de basse altitude ( $1150 \mathrm{~m}$ au dessus du niveau de la mer) Mwea (1 $025 \mathrm{~kg}$ d'ha-1). Le nombre de gousses par plante était fortement corrélé positivement au rendement en graines $\left(\mathrm{r}=0,85^{* * *}\right)$ et pourrait être adopté par les selectionneurs comme méthode de sélection indirecte pour le rendement en grains. L'interaction G x E sur le rendement en grain était élevée $(14,4 \%)$, ce qui implique que la plupart des génotypes devraient être sélectionnés et recommandés pour des environnements spécifiques. La lignée à haut rendement, KMA13-25-09 (3 $385 \mathrm{~kg}$ ha-1), était la moins stable sur tous les sites. Le score de gravité de la maladie pour les maladies visées était faible à intermédiaire, quels que soient les génotypes et les sites.

Mots Clés: Résistance aux maladies, Phaseolus vulgaris, sévérité

\section{INTRODUCTION}

Common bean (Phaseolus vulgaris L.) is a grain legume that provides dietary proteins, complex carbohydrate, micronutrients, vitamins and amino acids for over 300 million persons in tropical and subtropical regions (Graham et al., 2007; Assefa et al., 2015). Eastern Africa is one of the major producers and consumers of common bean (Beebe, 2012); though, its grain yields are among the lowest in the world $\left(<0.6 \mathrm{t} \mathrm{ha}^{-1}\right)$ due to several biotic and abiotic production limiting factors, among which drought, pests and diseases are the most important (Kimani et al., 2005). Although several diseases attack common beans in Kenya, angular leaf spot, anthracnose, common bacterial blight, bean common mosaic virus and the root roots are the most damaging, leading to substantial economic losses (Wortmann et al., 1998; Wagara and Kimani, 2007).

Breeding for resistance to biotic and abiotic stresses is the most practical and cost-effective strategy to improve grain yields and quality, by reducing losses associated with these production constraints (Okii et al., 2018). However, incorporating resistance to one pathogen may not result in a significant change because several diseases co-infection beans at the farm level. Consequently, breeding varieties with multiple disease resistance is a more appropriate, reliable and sustainable approach. Gamete selection method originally developed by Singh (1994) is the most efficient and effective method for multiple constraints breeding as it facilitates the concurrent improvement of several attributes in common bean.

Common bean varieties grown in Kenya are from the two recognised gene pools (Andean and Mesoamerican). The Andean cultivars are, by far, the most popular in Africa where they are preferred by farmers and consumers for their seed quality (Sichilima $e t$ al., 2016). However, they are characterised by a narrow to moderate genetic base, especially for grain yield potential and disease resistance, threatening progress towards improvement for these traits (Kimani et al., 2005; Asfaw et al., 2009; Okii et al., 2014). Broadening the genetic base of existing Andean commercial cultivars through inter-racial crosses, therefore, provides a unique opportunity for effective selection of improved cultivars with better agronomic potential. 
Mesoamerican genotypes have been used to improve Andean gene pool performance because they are better yielding and good sources of resistance to most of the diseases attacking Andean beans; and possess genes and high level of resistance to drought stress (Terán and Singh, 2002; Borel et al., 2013).

In bean breeding programmes, a large number of genotypes are tested for many generations within contrasting environments, before release for seed multiplication and distribution to farmers (Corrêa et al., 2015; 2016). As environmental conditions for testing are distinct, the genotype-environment interaction $(\mathrm{G} \times \mathrm{E})$ affects the agronomic performance, making it necessary to analyse the magnitude of that interaction on target traits, and the stability of new breeding lines across environments. Stability analysis through multisite testing is, therefore, important during selection because it provides information on specific or broader adaptation for a given genotype. The objective of this study was to assess the agronomic performance and yield stability of $24 \mathrm{~F}_{1.7}$ small red bean lines previously marker-selected for multiple disease resistance from 16 inter-racial populations in Kenya.

\section{MATERIALS AND METHODS}

Experimental sites. A field study was conducted during the 2017 short rain season from October 2017 to February 2018 in Kenya at three locations, representing low (1150 masl), medium (1820 masl) and high (2130 masl) altitude agro-ecological conditions. These sites included the Kenya Agricultural and Livestock Research Organisation (KALRO)Mwea (low altitude), KALRO-Tigoni (high altitude) and Kabete Field Station of the University of Nairobi (medium altitude). Characteristics of test sites are presented in Table 1.

Plant materials. Plant materials evaluated were $19 \mathrm{~F}_{1.7}$ small red bean lines selected from 16 inter-racial populations and five small red parents used as checks (GLP585, KATB9, G2333, RWR719 and G10909). GLP585, KATB9 and G2333 are commercial varieties grown in Eastern Africa. RWR719 is a breeding line developed in Rwanda, resistant to Pythium root rot (Otsyula et al., 2003), and G10909 is a CIAT accession with broad resistance to angular leaf spot (Mahuku et al., 2011). The 16 populations were developed from crosses

TABLE 1. Characteristics of the experimental sites used for bean lines testing in Kenya

\begin{tabular}{llll}
\hline Parameters & Kabete & Mwea & Tigoni \\
\hline Latitude & $01^{\circ} 15^{\prime} \mathrm{S}$ & $0^{\circ} 38^{\prime} \mathrm{S}$ & $01^{\circ} 08^{\prime} \mathrm{S}$ \\
Longitude & $36^{\circ} 44^{\prime} \mathrm{E}$ & $37^{\circ} 22^{\prime} \mathrm{E}$ & $36^{\circ} 40^{\prime} \mathrm{E}$ \\
Soil type & Humic nitisols & Acidic vertisol & Humic nitisols \\
Soil pH & 5.2 & 5.1 & 4.6 \\
Planting date & 25 October & 04 October & 23 October \\
Average temperature, ${ }^{\circ} \mathrm{C}$ & 18.2 & 22.6 & 15.3 \\
Maximum temperature, ${ }^{\circ} \mathrm{C}$ & 22.5 & 28.6 & 17.0 \\
Minimum temperature, ${ }^{\circ} \mathrm{C}$ & 12.3 & 15.6 & 12.9 \\
Annual rainfall, mm & 1059 & 807 & 1263 \\
Altitude, masl & 1820 & 1150 & 2130 \\
\hline
\end{tabular}

Source: https://en.climate-data.org/location (verified on 04 April 2018) 
among donor of resistance to major common bean diseases and commercial cultivars grown in Eastern Africa (Njuguna, 2014; Mondo et al., 2019). Among parental genotypes, Mex54 and G10909 were used as sources of resistance to angular leaf spot; G2333 to anthracnose; RWR719 and AND1062 to Pythium root rots; while BRB191 was for bean common mosaic virus. Although there are several pathogens attacking common beans in Kenya, target pathogens, namely angular leaf spot, anthracnose, common bacterial blight, bean common mosaic virus and root rots are the most damaging in farmers' fields (Wortmann et al., 1998; Wagara and Kimani, 2007). These pathogens may lead to significant yield losses, ranging from $20 \%$ to as high as $100 \%$, depending on grown cultivars and environmental conditions (Singh and Schwartz, 2010).

Four commercial varieties (GLP92, GLP585, KATB9 and KATB1) with high yield potential, high marketability and good adaptation to agro-ecological conditions of Eastern Africa; but susceptible to diseases were used as female parents. Crosses were made in 2009 and 2010 using the marker-assisted gamete selection procedure, as described by Singh (1994). Development of male gametes involved making single crosses in the first round of crossing. The single crosses were subsequently combined into double crosses during the second round of crossing. Male gametes with requisite resistance genes were then identified using markers SAB-3 for anthracnose; SH-13 for angular leaf spot; SW13 for bean common mosaic virus and PYAA19 for Pythium root rot. These male gametes were, thereafter, used to construct the $\mathrm{F}_{1}$ by the final cross of the double-cross gamete to the commercial varieties. The selection also started in $F_{1}$ instead of $F_{2}$ in normal cases.

A total of 16 populations was developed. The segregating $F_{1}$ and $F_{1.2}$ populations were then evaluated for agronomic attributes and tested for resistance to target diseases (angular leaf spot, anthracnose, common bacterial blight, bean common mosaic virus and Pythium root rot) under natural disease infestation, in the field at Kabete and Tigoni in Kenya, in 2011 and 2012. Molecular markers were used to screen the male gametes and the segregating $F_{1}$. Progenies were, thereafter, advanced following the gamete selection procedure up to $F_{1.6}$ from 2013 to 2016; and a single plant selection was performed at the $\mathrm{F}_{1.6}$ harvest to increase homozygosity and progression to pure lines in subsequent generations. Lines were considered to be nearly homozygous when they showed onegrain type, i.e., one seed colour. The populations were then grouped in market classes based on seed colour, shape and size.

The first two parameters were determined by physical observation during the seed processing stage; while seed size was determined based on the 100-seed mass: small ( $<25 \mathrm{~g} \mathrm{100-seed} \mathrm{mass);} \mathrm{medium} \mathrm{(} 25$ to $40 \mathrm{~g}$ 100 -seed mass) and large (>40 g 100-seed mass). Eight major market classes were distinguished from $\mathrm{F}_{1.6}$ segregating populations, including the red kidney, red mottled, small red, black, mixed colour, pinto, yellow and greyish green beans. This paper reports on small red bean lines generated by the abovedescribed breeding programme. Data on the other market classes were previously reported by Mondo et al. (2019). Crosses that produced these small red bean genotypes are presented in Table 2.

Treatments and design. Treatments included 24 small red bean genotypes tested in three contrasting environments, these comprised of $19 \mathrm{~F}_{1.7}$ lines and five checks. The experimental design was $5 \times 5$ lattice, with four replicates. Plots consisted of three $-4 \mathrm{~m}$ rows, with a density of 10 seeds per meter, and a row spacing of $0.5 \mathrm{~m}$. All field experiments were conducted during the short rain season (October 2017 to February 2018).

Diammonium phosphate (DAP) at a rate of $80 \mathrm{~kg} \mathrm{ha}^{-1}$ was applied following agronomic recommendations in the study area. Weeding 
TABLE 2. Crosses performed for populations' development that contributed to small red bean genotypes tested in this study

\begin{tabular}{llc}
\hline Population & Pedigree (cross) & Number of lines contributed \\
\hline KMA13-22 & GLP92 x G10909/G2333//RWR719/BRB191 & 2 \\
KMA13-23 & GLP92 x Mex54/G2333//AND1062/BRB191 & 2 \\
KMA13-25 & KATB1 x G10909/G2333//AND1062/BRB191 & 1 \\
KMA13-28 & KATB1 x Mex54/G2333//RWR719/BRB191 & 1 \\
KMA13-30 & KATB9 x G10909/G2333//RWR719/BRB191 & 4 \\
KMA13-31 & KATB9 x Mex54/G2333//AND1062/BRB191 & 7 \\
KMA13-32 & KATB9 x Mex54/G2333//RWR719/BRB191 & 2 \\
\hline
\end{tabular}

at all sites were carried out three times: two weeks after seedling emergence, before flowering and after podding. The pesticide Confidor (200 $\mathrm{g} \mathrm{l}^{-1}$ Imidacloprid) was used to control whiteflies and leaf miners.

Data collection and analysis. Data were collected on seedling emergence rate determined by dividing the total number of plants emerged over the total number of grains sown multiplied by 100 and expressed as a percentage. Plant vigour, also referred to as vegetative adaptation was recorded when plants reached their maximum development at R5 stage using the 1-9 CIAT scale; where 1 is excellent, 3 good, 5 intermediate, 7 poor, and 9 is very poor vigour. Days to $50 \%$ flowering was determined as the duration from the day of sowing to the day when at least $50 \%$ of flowers were opened. Growth habit was determined at R6 and R9 growth stages, plants were classified into four types: I = determinate, $\mathrm{II}=$ indeterminate, upright, III = indeterminate, prostrate and IV = climbing. Flower colour was determined by visual observation in the field during the flowering stage. Days to $75 \%$ physiological maturity was the duration from planting to the initiation of developmental stage R9 when $75 \%$ of the plants have reached physiological maturity.

Liebenberg (2002) scale was used to classify the genotypes in maturity classes: 85 94 days (early maturity); 95-104 days (medium maturity) and 105-115 days (late maturity). The number of pods per plant was obtained by the total count of pods produced per plant in each plot; while number of seeds per pod (expressed in numbers) was obtained by the total count of seeds per pod, 100-seed mass was obtained by the measurement of 100 seeds in a randomised procedure in each plot. Grain yield was the weight of seeds from rows of each plot dried to $13 \%$ moisture content. Harvest index was determined by dividing seed yield by the total plot biomass and expressed as a percentage). Diseases were scored using a 1 to 9 CIAT scale, where 1-3 being resistant, 4-6 intermediate resistant and 7-9 susceptible (Schoonhoven and Pastor-Corrales, 1987).

Statistical analysis on yield and yield related traits was performed using GenStat $15^{\text {th }}$ edition software (VSN International, 2012). Analysis of variance (ANOVA) was used to compare genotypes' means for all quantitative traits; while descriptive analysis was used for qualitative traits for which frequencies were calculated. ANOVA is an additive model in which the $G \times E$ interaction is a source of variation, but its intrinsic effects are not analysed. The additive main effect and multiplicative interaction (AMMI) model was, therefore, necessary to separate the additive variance from the $\mathrm{G} \times \mathrm{E}$ interaction (Gauch and Zobel, 1997; Gauch et al., 2008). The AMMI model used was: 
$\gamma_{g e r}=\mu+\alpha_{g}+\beta_{e}+\Sigma \lambda_{n} \gamma_{g n} \delta_{e n}+\rho_{g e}+$

$\boldsymbol{E}_{g \in r}$

Where:

$Y_{g e r}$ is the yield of genotype $g$ in the environment $e$ for replicate $r, \mu$ is the grand mean; $\alpha g$ is the genotype mean deviations; $\beta_{e}$ is the environment mean deviation; $n$ is the number of PCA axes retained in the model, $\lambda_{n}$ is singular value for PCA axis $\mathrm{n} ; \gamma_{g n}$ is the genotype eigenvector values for PCA axis n; $\delta_{e n}$ is the environment eigenvector values for PCA axis $\mathrm{n} ; \rho_{g e}$ represents the residuals; and $\varepsilon_{g e r}$ is for error.

AMMI analysis was also used to determine the stability of genotypes across locations, using the PCA scores (IPCA1 and IPCA2). The IPCA score near zero reveals more stable; while large values indicate more responsive and less stable genotypes. AMMI's stability value for seed yield was estimated as shown as follows (Purchase, 1997):

$$
\text { ASV }=\sqrt{\left[\frac{\text { SS IPCA 1 }}{\text { SS IPCA 2 }} \text { (IPCA 1 Score) }\right]^{2}+}
$$

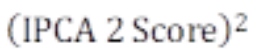

Where:

ASV is the AMMI stability value, SS IPCA 1 and SS IPCA 2 are sum of squares of IPCA 1 and 2, respectively, and IPCA is the interaction principal component analysis. Thus, the least ASV indicates a wide adaptation of specific genotypes for certain environments and viceversa.

GGE (Genotype main effect plus genotype by environment interaction) biplot was used to determine the adaptation of genotypes and their stability across test environments. From this analysis, genotypes located near the biplot origin are considered widely adapted; while genotypes located far are specifically adapted. All the genotypes with positive IPCA1 scores responded positively to the environment having positive IPCA1 scores, and are, therefore, adapted to that particular environment (Samonte et al., 2005).

\section{RESULTS}

\section{Seedling emergence rate, growth habit and} flower colour. There were highly significant location differences $(\mathrm{P}<0.001)$, as well as site $\mathrm{x}$ genotype interaction $(\mathrm{P}<0.05)$ for seedling emergence rate (Table 3). On the other hand, genotype effects were not significant. Seedling emergence rate ranged from 38.7 to $93.7 \%$. The highest mean seedling emergence rate was at Kabete in medium altitude $(77.6 \%)$, and the lowest at high altitude Tigoni site (58.9\%). Among the study lines, KMA13-22-27 had the highest seedling emergence rate $(93.7 \%$ at Kabete), compared to all other lines and checks. KMA13-28-13 (38.7\%) had the lowest seedling emergence rate, which was recorded at Tigoni.

Most of the advanced small red bean lines had white flowers and a growth habit ranging from determinate growth habit (Type I) to indeterminate climbing growth habit (Type IV), with Types III and IV being the most predominant (Table 3 ).

Plant vigour. Table 4 shows a significant site $(\mathrm{P}<0.001)$ and genotypic $(\mathrm{P}<0.01)$ differences in plant vigour among small red bean lines. However, the genotype $\mathrm{x}$ site interaction was not significant. The study lines grew vigorously at Tigoni in high altitude (2.4), compared to Mwea (4.4) and Kabete (4.6) in low and medium altitudes, respectively. Line KMA13-23-14 was, in general, the most vigorous regardless of sites (3.3) and compared to all the lines and checks. In contrast, KMA13-31-09 was the least vigorous among lines and check varieties (4.7); and it 
TABLE 3. Seedling behaviour, growth habit and flower colour of small red $\mathrm{F}_{1.7}$ bean lines grown at multilocations in Kenya

\begin{tabular}{|c|c|c|c|c|c|c|}
\hline \multirow[t]{2}{*}{ Line } & \multicolumn{4}{|c|}{ Seedling emergence rate $(\%)$} & \multirow{2}{*}{$\begin{array}{c}\text { Growth } \\
\text { habit }\end{array}$} & \multirow{2}{*}{$\begin{array}{c}\text { Flower } \\
\text { colour }\end{array}$} \\
\hline & Kabete & Mwea & Tigoni & Mean & & \\
\hline KMA13-22-27 & 93.7 & 62.5 & 51.2 & 69.2 & IV & White \\
\hline KMA13-22-29 & 78.7 & 85.0 & 50.0 & 71.2 & I & White \\
\hline KMA13-23-14 & 68.7 & 68.7 & 45.0 & 60.8 & IV & White \\
\hline KMA13-23-21 & 75.0 & 73.7 & 52.5 & 67.1 & IV & Purple \\
\hline KMA13-25-09 & 83.7 & 66.2 & 42.5 & 64.2 & IV & White \\
\hline KMA13-28-13 & 86.2 & 73.7 & 38.7 & 66.2 & IV & White \\
\hline KMA13-30-02 & 78.7 & 61.2 & 67.5 & 69.2 & III & White \\
\hline KMA13-30-14 & 71.2 & 75.0 & 56.2 & 67.5 & III & White \\
\hline KMA13-30-16 & 83.7 & 71.2 & 61.2 & 72.1 & IV & White \\
\hline KMA13-30-30 & 77.5 & 53.7 & 68.7 & 66.7 & III & White \\
\hline KMA13-31-01 & 82.5 & 70.0 & 43.7 & 65.4 & III & White \\
\hline KMA13-31-03 & 77.5 & 81.2 & 71.2 & 76.7 & III & White \\
\hline KMA13-31-04 & 86.2 & 72.5 & 67.5 & 75.4 & III & White \\
\hline KMA13-31-05 & 71.2 & 67.5 & 42.5 & 60.4 & III & White \\
\hline KMA13-31-06 & 80.0 & 57.5 & 51.2 & 62.9 & III & White \\
\hline KMA13-31-08 & 78.7 & 68.7 & 62.5 & 70.0 & III & White \\
\hline KMA13-31-09 & 76.2 & 70.0 & 68.7 & 71.7 & II & White \\
\hline KMA13-32-26 & 76.2 & 58.7 & 76.2 & 70.4 & I & Purple \\
\hline KMA13-32-28 & 81.2 & 52.5 & 72.5 & 68.7 & III & Purple \\
\hline G10909 & 76.2 & 81.2 & 66.2 & 74.6 & IV & White \\
\hline G2333 & 67.5 & 38.7 & 71.2 & 59.2 & IV & White \\
\hline GLP585 & 61.2 & 53.7 & 65.0 & 60.0 & I & White \\
\hline KATB9 & 81.2 & 48.7 & 55.0 & 61.7 & I & Purple \\
\hline RWR719 & 70.0 & 61.2 & 66.2 & 65.8 & II & Purple \\
\hline Mean & 77.6 & 65.6 & 58.9 & 67.4 & & \\
\hline $\mathrm{CV}(\%)$ & 21.4 & & & & & \\
\hline $\mathrm{LSD}_{0.05}$ & Line $=1$ & Site $=4.1$ & $\mathrm{x}$ site $=2$ & & & \\
\hline
\end{tabular}

$\mathrm{CV}=$ coefficient of variation; $\mathrm{LSD}=$ least significant difference at $\mathrm{P}$-value threshold of 0.05

was statistically equal to the check variety RWR719.

Duration to flowering and maturity. There were significant site and genotypic differences $(\mathrm{P}<0.001)$ among the small red bean lines for the days to flowering and the days to maturity (Table 5). The interaction between sites and genotypes was also significant $(\mathrm{P}<0.05)$. Duration of day to flowering was shorter at the low altitude Mwea site (39.8 days) than at the medium altitude Kabete (43.1 days) and high altitude Tigoni (49.9 days) sites. The trend was the same for the days to maturity, with 89.4, 95.2 and 106.2 days at Mwea, Kabete and Tigoni, respectively. Among the small red bean lines, KMA13-32-26 was the earliest to flower (39.2 days) regardless of the site. It was also the earliest to mature compared to all lines and all the check varieties (88.3 days) (Table 5). 
TABLE 4. Plant vigour of small red $\mathrm{F}_{1.7}$ bean lines grown at various locations in Kenya

\begin{tabular}{|c|c|c|c|c|}
\hline Line & Kabete & Mwea & Tigoni & Mean \\
\hline KMA13-22-27 & 4.5 & 4.2 & 2.7 & 3.8 \\
\hline KMA13-22-29 & 5.0 & 4.5 & 1.7 & 3.7 \\
\hline KMA13-23-14 & 4.2 & 3.5 & 2.2 & 3.3 \\
\hline KMA13-23-21 & 5.2 & 3.7 & 2.0 & 3.7 \\
\hline KMA13-25-09 & 4.7 & 4.2 & 1.2 & 3.4 \\
\hline KMA13-28-13 & 4.0 & 3.7 & 3.0 & 3.6 \\
\hline KMA13-30-02 & 4.2 & 5.0 & 2.2 & 3.8 \\
\hline KMA13-30-14 & 4.5 & 4.0 & 2.2 & 3.6 \\
\hline KMA13-30-16 & 4.2 & 3.7 & 2.2 & 3.4 \\
\hline KMA13-30-30 & 4.2 & 4.2 & 2.5 & 3.7 \\
\hline KMA13-31-01 & 4.7 & 4.2 & 2.2 & 3.7 \\
\hline KMA13-31-03 & 5.0 & 4.7 & 2.7 & 4.1 \\
\hline KMA13-31-04 & 4.2 & 4.2 & 2.2 & 3.6 \\
\hline KMA13-31-05 & 5.0 & 3.7 & 2.5 & 3.7 \\
\hline KMA13-31-06 & 4.5 & 4.2 & 2.2 & 3.7 \\
\hline KMA13-31-08 & 4.2 & 4.0 & 2.7 & 3.7 \\
\hline KMA13-31-09 & 5.5 & 6.0 & 2.5 & 4.7 \\
\hline KMA13-32-26 & 3.7 & 5.0 & 2.0 & 3.6 \\
\hline KMA13-32-28 & 4.0 & 4.0 & 2.5 & 3.5 \\
\hline G10909 & 4.5 & 4.2 & 2.3 & 3.7 \\
\hline G2333 & 4.7 & 4.3 & 2.8 & 3.9 \\
\hline GLP585 & 5.7 & 5.0 & 2.5 & 4.4 \\
\hline KATB9 & 4.5 & 5.3 & 2.8 & 4.2 \\
\hline RWR719 & 6.0 & 4.8 & 3.5 & 4.7 \\
\hline Mean & 4.6 & 4.4 & 2.4 & 3.8 \\
\hline $\mathrm{CV}(\%)$ & 23.4 & & & \\
\hline
\end{tabular}

$\mathrm{CV}=$ coefficient of variation; $\mathrm{LSD}=$ least significant difference at $\mathrm{P}$-value threshold of 0.05

Number of pods per plant. There were highly significant site and genotypic differences for the number of pods per plant among the small red bean lines (Table 6). Interactions between genotypes and sites were also highly significant $(\mathrm{P}<0.001)$ for pods plant ${ }^{-1}$. Test lines had the highest number of pods per plant (26.2) at Tigoni, which was significantly higher compared to Kabete (8.6) and Mwea (6.8) (Table 6). Among test lines, KMA13-23-14 (22.7 pods plant ${ }^{-1}$ ) had the highest number of pods per plant. This line produced significantly more pods than other advanced small red bean lines and check varieties. RWR719, with an average of 7.9 pods plant $^{-1}$, had the lowest number of pods per plant.

Number of seeds per pod. Results showed significant differences for the number of seeds pod $^{-1}$ among the small red bean lines, due to the genotypic $(\mathrm{P}<0.001)$, sites $(\mathrm{P}<0.01)$ and their interactions $(\mathrm{P}<0.001)$ (Table 7). Among the sites, the number of seeds pod ${ }^{-1}$ obtained from Kabete (5.9) was not significantly different from that at Mwea (5.8). However, the test lines had more seeds $\operatorname{pod}^{-1}(6.1)$ at Tigoni compared to the other two sites. KMA13-32-28 with a mean of 7.6 seeds pod 
TABLE 5. Duration to flowering and to maturity among small red $\mathrm{F}_{1.7}$ bean lines grown at various locations in Kenya

\begin{tabular}{|c|c|c|c|c|c|c|c|c|c|}
\hline \multirow{2}{*}{$\begin{array}{l}\text { Lines } \\
\text { Sites }\end{array}$} & \multicolumn{4}{|c|}{ Days to flowering } & \multicolumn{4}{|c|}{ Days to maturity } & \multirow[t]{2}{*}{ Maturity class } \\
\hline & Kabete & Mwea & Tigoni & Mean & Kabete & Mwea & Tigoni & Mean & \\
\hline KMA13-22-27 & 43.5 & 39.5 & 51.0 & 44.7 & 95.5 & 90.0 & 112.0 & 99.2 & Medium maturity \\
\hline KMA13-22-29 & 45.5 & 41.0 & 52.5 & 46.3 & 94.5 & 85.0 & 103.0 & 94.2 & Early maturity \\
\hline KMA13-23-14 & 43.5 & 39.5 & 50.0 & 44.3 & 98.0 & 85.5 & 108.5 & 97.3 & Medium maturity \\
\hline KMA13-23-21 & 47.0 & 43.5 & 53.0 & 47.8 & 102.5 & 90.0 & 113.5 & 102.0 & Medium maturity \\
\hline KMA13-25-09 & 44.5 & 40.5 & 52.0 & 45.7 & 100.0 & 91.5 & 109.0 & 100.2 & Medium maturity \\
\hline KMA13-28-13 & 44.0 & 39.5 & 52.5 & 45.3 & 94.0 & 92.5 & 106.5 & 97.7 & Medium maturity \\
\hline KMA13-30-02 & 40.0 & 38.0 & 48.0 & 42.0 & 94.0 & 88.0 & 108.5 & 96.8 & Medium maturity \\
\hline KMA13-30-14 & 42.5 & 39.5 & 51.0 & 44.3 & 97.0 & 91.0 & 110.0 & 99.3 & Medium maturity \\
\hline KMA13-30-16 & 44.0 & 40.0 & 50.0 & 44.7 & 99.0 & 89.5 & 108.0 & 98.8 & Medium maturity \\
\hline KMA13-30-30 & 43.0 & 39.5 & 50.5 & 44.3 & 95.0 & 91.0 & 101.0 & 95.7 & Medium maturity \\
\hline KMA13-31-01 & 42.5 & 40.0 & 50.0 & 44.2 & 93.0 & 87.0 & 101.0 & 93.7 & Early maturity \\
\hline KMA13-31-03 & 43.5 & 40.0 & 49.5 & 44.3 & 93.0 & 89.0 & 100.0 & 94.0 & Early maturity \\
\hline KMA13-31-04 & 42.5 & 40.0 & 49.5 & 44.0 & 90.0 & 87.0 & 106.5 & 94.5 & Early maturity \\
\hline KMA13-31-05 & 42.5 & 39.5 & 49.5 & 43.8 & 94.0 & 92.0 & 105.0 & 97.0 & Medium maturity \\
\hline KMA13-31-06 & 42.5 & 40.0 & 50.0 & 44.2 & 93.5 & 87.5 & 101.0 & 94.0 & Early maturity \\
\hline KMA13-31-08 & 43.5 & 39.5 & 50.0 & 44.3 & 94.0 & 91.0 & 107.0 & 97.3 & Medium maturity \\
\hline KMA13-31-09 & 44.5 & 40.5 & 49.0 & 44.7 & 95.5 & 89.0 & 100.0 & 94.8 & Early maturity \\
\hline KMA13-32-26 & 38.0 & 36.7 & 43.0 & 39.2 & 83.5 & 85.0 & 96.5 & 88.3 & Early maturity \\
\hline KMA13-32-28 & 38.0 & 37.0 & 44.0 & 39.7 & 95.5 & 91.0 & 109.5 & 98.7 & Medium maturity \\
\hline G10909 & 44.0 & 40.0 & 51.0 & 45.0 & 97.5 & 91.0 & 109.0 & 99.2 & Medium maturity \\
\hline G2333 & 44.0 & 41.0 & 51.2 & 45.4 & 99.5 & 91.0 & 109.5 & 100.0 & Medium maturity \\
\hline GLP585 & 45.5 & 40.5 & 51.5 & 45.8 & 97.0 & 89.5 & 107.0 & 97.8 & Medium maturity \\
\hline KATB9 & 40.5 & 39.5 & 47.0 & 42.3 & 91.5 & 89.0 & 103.5 & 94.7 & Early maturity \\
\hline RWR719 & 45.0 & 40.5 & 52.5 & 46.0 & 98.5 & 92.5 & 113.0 & 101.3 & Medium maturity \\
\hline Mean & 43.1 & 39.8 & 49.9 & 44.3 & 95.2 & 89.4 & 106.2 & 96.9 & \\
\hline $\mathrm{CV}(\%)$ & 2.7 & & & & 3.0 & & & & \\
\hline $\mathrm{LSD}_{0.05}$ & \multicolumn{2}{|c|}{ Line $=1.0$, Site $=0.3$} & Line $\mathrm{x}$ site & & \multicolumn{5}{|c|}{ Line $=2.3$, Site $=0.8$, Line $x$ site $=4.0$} \\
\hline
\end{tabular}

$\mathrm{CV}=$ coefficient of variation; $\mathrm{LSD}=$ least significant difference at $\mathrm{P}$-value threshold of 0.05 
TABLE 6. Number of pods per plant of small red $\mathrm{F}_{1.7}$ bean lines grown at various locations in Kenya

\begin{tabular}{|c|c|c|c|c|}
\hline Line & Kabete & Mwea & Tigoni & Mean \\
\hline KMA13-22-27 & 6.3 & 4.3 & 21.9 & 10.8 \\
\hline KMA13-22-29 & 9.4 & 6.0 & 39.3 & 18.2 \\
\hline KMA13-23-14 & 8.6 & 13.3 & 46.1 & 22.7 \\
\hline KMA13-23-21 & 7.9 & 7.3 & 27.2 & 14.1 \\
\hline KMA13-25-09 & 10.0 & 8.0 & 41.4 & 19.8 \\
\hline KMA13-28-13 & 7.6 & 6.3 & 20.2 & 11.4 \\
\hline KMA13-30-02 & 7.4 & 6.2 & 36.2 & 16.6 \\
\hline KMA13-30-14 & 7.0 & 7.8 & 31.7 & 15.5 \\
\hline KMA13-30-16 & 7.1 & 7.8 & 25.9 & 13.6 \\
\hline KMA13-30-30 & 6.5 & 5.1 & 13.2 & 8.3 \\
\hline KMA13-31-01 & 10.0 & 9.0 & 28.9 & 16.0 \\
\hline KMA13-31-03 & 7.1 & 6.7 & 26.0 & 13.3 \\
\hline KMA13-31-04 & 9.4 & 6.3 & 22.2 & 12.7 \\
\hline KMA13-31-05 & 4.6 & 9.6 & 31.7 & 15.3 \\
\hline KMA13-31-06 & 11.3 & 6.5 & 26.8 & 14.9 \\
\hline KMA13-31-08 & 9.6 & 7.0 & 20.0 & 12.2 \\
\hline KMA13-31-09 & 8.0 & 4.8 & 23.9 & 12.3 \\
\hline KMA13-32-26 & 8.6 & 3.0 & 14.5 & 9.8 \\
\hline KMA13-32-28 & 8.6 & 11.3 & 20.2 & 13.3 \\
\hline RWR719 & 7.1 & 2.6 & 13.9 & 7.9 \\
\hline G10909 & 9.3 & 4.2 & 17.1 & 10.2 \\
\hline G2333 & 11.9 & 6.7 & 30.2 & 16.2 \\
\hline GLP585 & 7.7 & 6.0 & 23.5 & 12.4 \\
\hline KATB9 & 15.1 & 6.5 & 26.9 & 16.2 \\
\hline Mean & 8.6 & 6.8 & 26.2 & 13.9 \\
\hline $\mathrm{CV}(\%)$ & 44.1 & & & \\
\hline \multicolumn{5}{|c|}{$\mathrm{LSD}_{0.05}:$ Line $=4.9$, Site $=1.7$, Line $x$ site $=8.5$} \\
\hline
\end{tabular}

$\mathrm{CV}=$ coefficient of variation; $\mathrm{LSD}=$ least significant difference at $\mathrm{P}$-value threshold of 0.05

${ }^{1}$ and KMA13-25-09 with 7.0 seeds pod $^{-1}$ had the highest number of seeds per pod compared with all other small red bean lines and check varieties (Table 7).

100-seed mass and seed size. There were highly significant differences among the small red bean lines for the 100-seed mass (Table 8 ), attributed to genotypic and site effects; and their interactions $(\mathrm{P}<0.001)$. Seed size ranged

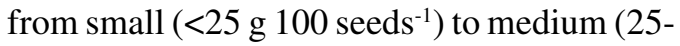

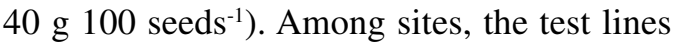
had largest seeds at Tigoni (28.8 g 100 seeds $^{-1}$ ) compared to Kabete (25.8 g 100 seeds $^{-1}$ ) and Mwea (24.5 g 100 seeds $\left.^{-1}\right)$. KMA13-23-21 had the largest seeds (39.0 $\mathrm{g}$ 100 seeds $^{-1}$ ). In contrast, KMA13-31-04 had

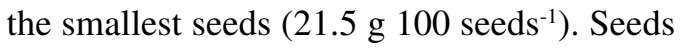
of this line were smaller than that of all the advanced lines and check varieties (Table 8).

Grain yield. There were highly significant differences for the grain yield, attributed to genotypic effects, sites and to their interactions $(\mathrm{P}<0.001)$. Among sites, Tigoni produced the highest grain yield $\left(3,808.6 \mathrm{~kg} \mathrm{ha}^{-1}\right)$, which was significantly higher than the grain yield recorded at Kabete $\left(1,100.1 \mathrm{~kg} \mathrm{ha}^{-1}\right)$ and Mwea 
TABLE 7. Number of seeds per pod of the small red $\mathrm{F}_{1.7}$ bean lines grown at various locations in Kenya

\begin{tabular}{|c|c|c|c|c|}
\hline Line & Kabete & Mwea & Tigoni & Mean \\
\hline KMA13-22-27 & 7.3 & 6.3 & 6.5 & 6.7 \\
\hline KMA13-22-29 & 4.3 & 4.4 & 5.1 & 4.6 \\
\hline KMA13-23-14 & 5.8 & 5.9 & 5.4 & 5.7 \\
\hline KMA13-23-21 & 5.3 & 4.0 & 4.8 & 4.7 \\
\hline KMA13-25-09 & 7.9 & 5.5 & 7.6 & 7.0 \\
\hline KMA13-28-13 & 5.1 & 4.8 & 6.1 & 5.4 \\
\hline KMA13-30-02 & 5.4 & 5.0 & 6.6 & 5.7 \\
\hline KMA13-30-14 & 6.4 & 6.2 & 6.3 & 6.3 \\
\hline KMA13-30-16 & 5.6 & 5.0 & 4.9 & 5.2 \\
\hline KMA13-30-30 & 5.5 & 7.0 & 5.6 & 6.0 \\
\hline KMA13-31-01 & 5.9 & 6.3 & 5.6 & 5.9 \\
\hline KMA13-31-03 & 6.1 & 5.6 & 6.4 & 6.0 \\
\hline KMA13-31-04 & 6.3 & 5.1 & 5.8 & 5.7 \\
\hline KMA13-31-05 & 6.0 & 6.6 & 6.3 & 6.3 \\
\hline KMA13-31-06 & 5.9 & 6.0 & 6.4 & 6.1 \\
\hline KMA13-31-08 & 5.8 & 5.9 & 6.9 & 6.2 \\
\hline KMA13-31-09 & 7.1 & 6.3 & 5.8 & 6.4 \\
\hline KMA13-32-26 & 4.0 & 4.5 & 4.5 & 4.3 \\
\hline KMA13-32-28 & 7.3 & 7.6 & 8.0 & 7.6 \\
\hline RWR719 & 6.1 & 5.6 & 6.9 & 6.2 \\
\hline G10909 & 6.6 & 6.9 & 7.0 & 6.8 \\
\hline G2333 & 6.0 & 6.3 & 7.0 & 6.4 \\
\hline GLP585 & 5.8 & 6.5 & 7.4 & 6.5 \\
\hline KATB9 & 5.1 & 5.3 & 4.6 & 5.0 \\
\hline Mean & 5.9 & 5.8 & 6.1 & 6.0 \\
\hline $\mathrm{CV}(\%)$ & 12.0 & & & \\
\hline \multicolumn{5}{|c|}{$\mathrm{LSD}_{0.05}:$ Line $=0.6$, Site $=0.2$, Line $x$ site $=1.0$} \\
\hline
\end{tabular}

$\mathrm{CV}=$ coefficient of variation; $\mathrm{LSD}=$ least significant difference at $\mathrm{P}$-value threshold of 0.05

$\left(1,051.1 \mathrm{~kg} \mathrm{ha}^{-1}\right)$. Differences in grain yield between Kabete and Mwea were not significant. KMA13-25-09 (3,385.2 $\left.\mathrm{kg} \mathrm{ha}^{-1}\right)$ and KMA13-23-14 (3,021.6 $\left.\mathrm{kg} \mathrm{ha}^{-1}\right)$ were the best yielding lines, and superior to all the other small red bean lines and check varieties. All other small red bean lines were either statistically equal or inferior to the best check variety G2333 (2,900.7 $\left.\mathrm{kg} \mathrm{ha}^{-1}\right)$ (Table 9).

Harvest index. There were highly significant differences among advanced small red bean lines for the harvest index due to genotypes, sites and to the interactions $(\mathrm{P}<0.001)$. Among the test sites, Tigoni recorded the highest mean harvest index $(60.4 \%)$ compared to Kabete (41.3\%) and Mwea (38.4\%). KMA13-31-04 had the highest mean for the harvest index $(60.5 \%)$ among the test lines. However, the harvest index of KMA13-31-04 was inferior to that of the check variety KATB9 $(66.4 \%)$ (Table 10).

\section{Yield stability analysis}

Analysis of variance. Table 11 shows highly significant $(\mathrm{P}<0.001)$ effects of genotypes and environments, and their interactions on seed 
TABLE 8. 100-seed mass (in $\mathrm{g}$ ) of small red $\mathrm{F}_{1.7}$ bean lines grown at various locations in Kenya

\begin{tabular}{|c|c|c|c|c|}
\hline Line & Kabete & Mwea & Tigoni & Mean \\
\hline KMA13-22-27 & 24.5 & 21.7 & 30.0 & 25.4 \\
\hline KMA13-22-29 & 26.6 & 21.5 & 28.7 & 25.6 \\
\hline KMA13-23-14 & 25.9 & 25.0 & 32.4 & 27.7 \\
\hline KMA13-23-21 & 40.8 & 36.5 & 39.6 & 39.0 \\
\hline KMA13-25-09 & 27.8 & 26.7 & 27.6 & 27.3 \\
\hline KMA13-28-13 & 24.2 & 22.7 & 28.9 & 25.3 \\
\hline KMA13-30-02 & 20.4 & 23.9 & 27.8 & 24.0 \\
\hline KMA13-30-14 & 30.0 & 28.8 & 29.5 & 29.4 \\
\hline KMA13-30-16 & 31.9 & 36.3 & 35.5 & 34.5 \\
\hline KMA13-30-30 & 26.5 & 25.0 & 29.7 & 27.0 \\
\hline KMA13-31-01 & 22.3 & 24.8 & 24.6 & 23.9 \\
\hline KMA13-31-03 & 23.6 & 20.8 & 24.6 & 23.0 \\
\hline KMA13-31-04 & 19.1 & 18.7 & 26.8 & 21.5 \\
\hline KMA13-31-05 & 25.6 & 24.5 & 26.3 & 25.4 \\
\hline KMA13-31-06 & 21.5 & 22.6 & 25.0 & 23.0 \\
\hline KMA13-31-08 & 22.2 & 21.7 & 24.5 & 22.8 \\
\hline KMA13-31-09 & 25.6 & 20.1 & 24.6 & 23.4 \\
\hline KMA13-32-26 & 34.5 & 28.3 & 40.3 & 35.6 \\
\hline KMA13-32-28 & 26.7 & 24.7 & 30.7 & 27.4 \\
\hline RWR719 & 21.4 & 22.1 & 21.9 & 21.8 \\
\hline G10909 & 24.3 & 22.2 & 28.4 & 25.0 \\
\hline G2333 & 24.4 & 22.5 & 27.2 & 24.7 \\
\hline GLP585 & 25.4 & 24.4 & 28.5 & 26.1 \\
\hline KATB9 & 24.9 & 23.9 & 28.4 & 25.7 \\
\hline Mean & 25.8 & 24.5 & 28.8 & 26.4 \\
\hline $\mathrm{CV}(\%)$ & 9.3 & & & \\
\hline
\end{tabular}

$\mathrm{CV}=$ coefficient of variation; $\mathrm{LSD}=$ least significant difference at $\mathrm{P}$-value threshold of 0.05

yield of the small red market class. Treatments contribution to the total variability was $79.9 \%$. Partitioning that variability revealed that $68.0 \%$ was contributed by the environments, 17.6 and $14.4 \%$ of treatment variability were contributed by the genotypes and the interactions between genotypes and environments, respectively. IPCA1 yielded the highest amount of $\mathrm{G} \times \mathrm{E}$ effects on seed yield (88.9\%).

AMMI model ranking and AMMI stability value. Table 12 shows that the best yield was recorded at the high altitude of Tigoni site $\left(3,809 \mathrm{~kg} \mathrm{ha}^{-1}\right)$. Grain yield at Tigoni was significantly higher $(\mathrm{P}<0.01)$ than that at the two other sites. However, yield differences between the medium altitude site at Kabete $\left(1,100 \mathrm{~kg} \mathrm{ha}^{-1}\right)$ and the low altitude Mwea site $\left(1,025 \mathrm{~kg} \mathrm{ha}^{-1}\right)$ were not statistically significant. Among test lines, SR5 (KMA1325-09) and SR3 (KMA13-23-14) were the best yielding genotypes, with mean seed yields of 3,385 and 3,022 $\mathrm{kg} \mathrm{ha}^{-1}$, respectively. These two lines were superior to all the small red bean lines and the check varieties. Other lines were either statistically equal to or lower than 
TABLE 9. Grain yield $\left(\mathrm{kg} \mathrm{ha}^{-1}\right)$ of the small red $\mathrm{F}_{1.7}$ bean lines grown at various locations in Kenya

\begin{tabular}{|c|c|c|c|c|}
\hline Line & Kabete & Mwea & Tigoni & Mean \\
\hline KMA13-22-27 & 701.6 & 399.3 & $5,095.6$ & $2,065.5$ \\
\hline KMA13-22-29 & 783.6 & 648.2 & $2,960.2$ & $1,464.0$ \\
\hline KMA13-23-14 & $1,202.8$ & $1,779.1$ & $6,083.0$ & $3,021.6$ \\
\hline KMA13-23-21 & $1,090.3$ & $1,440.5$ & $3,357.6$ & $1,962.8$ \\
\hline KMA13-25-09 & $1,362.3$ & $1,983.5$ & $6,809.8$ & $3,385.2$ \\
\hline KMA13-28-13 & 862.9 & 515.3 & $2,636.5$ & $1,338.2$ \\
\hline KMA13-30-02 & 850.7 & 705.6 & $3,506.3$ & $1,687.5$ \\
\hline KMA13-30-14 & $1,364.4$ & 905.1 & $6,090.4$ & $2,786.6$ \\
\hline KMA13-30-16 & $1,553.2$ & $2,267.3$ & $4,198.8$ & $2,673.1$ \\
\hline KMA13-30-30 & 848.9 & 603.8 & $1,579.1$ & $1,010.6$ \\
\hline KMA13-31-01 & 961.4 & $1,496.7$ & $3,975.0$ & $2,144.4$ \\
\hline KMA13-31-03 & 943.0 & 708.9 & $2,150.7$ & $1,267.6$ \\
\hline KMA13-31-04 & 906.2 & $1,354.2$ & $3,678.6$ & $1,979.7$ \\
\hline KMA13-31-05 & $1,091.9$ & $1,525.1$ & $4,320.1$ & $2,312.4$ \\
\hline KMA13-31-06 & $1,100.4$ & $1,205.7$ & $4,340.1$ & $2,215.4$ \\
\hline KMA13-31-08 & $1,049.7$ & 805.9 & $2,278.7$ & $1,378.1$ \\
\hline KMA13-31-09 & $1,124.5$ & 477.0 & $2,175.5$ & $1,259.0$ \\
\hline KMA13-32-26 & 660.8 & 518.4 & 2,199.9 & $1,248.0$ \\
\hline KMA13-32-28 & $1,048.8$ & $1,702.1$ & $4,606.9$ & $2,452.6$ \\
\hline RWR719 & 700.5 & 505.3 & $2,192.6$ & $1,132.8$ \\
\hline G10909 & $1,744.3$ & 597.1 & $4,186.7$ & $2,176.0$ \\
\hline G2333 & $1,938.6$ & $1,356.3$ & $5,407.4$ & $2,900.7$ \\
\hline GLP585 & $1,079.3$ & 858.7 & $4,676.0$ & $2,204.7$ \\
\hline KATB9 & $1,431.3$ & 601.4 & 2,901.9 & $1,644.9$ \\
\hline Mean & $1,100.1$ & $1,051.1$ & $3,808.6$ & $1,993.2$ \\
\hline $\mathrm{CV}(\%)$ & 39.8 & & & \\
\hline
\end{tabular}

$\mathrm{CV}=$ coefficient of variation; $\mathrm{LSD}=$ least significant difference at $\mathrm{P}$-value threshold of 0.05

the check varieties. G2333, the best check variety had a mean yield of $2,901 \mathrm{~kg} \mathrm{ha}^{-1}$. The least productive line was SR18 (KMA13-3226) $\left(1,005 \mathrm{~kg} \mathrm{ha}^{-1}\right)$.

AMMI stability value (ASV) scores ranged from 1.2 to 31.0. SR7 (KMA13-30-02) was the most stable line across environments, bearing an ASV score of 1.2. Other stable genotypes included SR15 (KMA13-31-06), SR2 (KMA13-22-29), SR14 (KMA13-31-05) and SR13 (KMA13-31-04), with ASV scores of $6.0,6.2,9.0$ and 9.6, respectively. The best yielding line SR5 (KMA13-25-09) was also the least stable across locations (ASV=31.0). Based on AMMI analysis, the most adapted lines were SR5 (KMA13-25-09), SR8 (KMA13-30-14), SR3 (KMA13-23-14) and SR24 (G2333), for high altitude; SR24 (G2333), SR23 (G10909), SR9 (KMA13-3016), SR20 (KATB9) for medium altitude and SR9 (KMA13-30-16), SR5 (KMA13-25-09), SR3 (KMA13-23-14), SR19 (KMA13-32-28) in low altitude (Table 12).

GGE biplot for $\mathbf{G} \times \mathbf{E}$ analysis. Figure 1 presents the impression of "which won where" 
TABLE 10. Harvest index (in \%) of small red $\mathrm{F}_{1.7}$ bean lines grown at various locations in Kenya

\begin{tabular}{|c|c|c|c|c|}
\hline Line & Kabete & Mwea & Tigoni & Mean \\
\hline KMA13-22-27 & 42.9 & 18.8 & 64.9 & 42.2 \\
\hline KMA13-22-29 & 49.9 & 41.7 & 55.5 & 49.1 \\
\hline KMA13-23-14 & 40.6 & 34.5 & 71.6 & 48.9 \\
\hline KMA13-23-21 & 23.8 & 26.2 & 38.2 & 29.4 \\
\hline KMA13-25-09 & 33.0 & 22.8 & 56.4 & 37.4 \\
\hline KMA13-28-13 & 51.6 & 23.1 & 45.4 & 40.1 \\
\hline KMA13-30-02 & 37.3 & 59.6 & 53.8 & 50.2 \\
\hline KMA13-30-14 & 41.6 & 10.8 & 77.4 & 43.3 \\
\hline KMA13-30-16 & 39.3 & 30.5 & 65.0 & 44.9 \\
\hline KMA13-30-30 & 33.8 & 49.7 & 50.4 & 44.6 \\
\hline KMA13-31-01 & 41.2 & 36.5 & 53.8 & 43.8 \\
\hline KMA13-31-03 & 38.5 & 61.5 & 54.5 & 51.5 \\
\hline KMA13-31-04 & 49.7 & 68.0 & 63.8 & 60.5 \\
\hline KMA13-31-05 & 43.1 & 73.2 & 59.4 & 58.6 \\
\hline KMA13-31-06 & 46.0 & 66.9 & 64.6 & 59.2 \\
\hline KMA13-31-08 & 45.9 & 35.3 & 66.5 & 49.2 \\
\hline KMA13-31-09 & 45.3 & 32.4 & 51.2 & 43.0 \\
\hline KMA13-32-26 & 35.4 & 52.2 & 54.1 & 46.2 \\
\hline KMA13-32-28 & 41.4 & 35.5 & 82.6 & 53.2 \\
\hline RWR719 & 19.9 & 13.4 & 54.2 & 29.1 \\
\hline G10909 & 44.9 & 20.5 & 72.8 & 46.1 \\
\hline G2333 & 47.7 & 20.2 & 64.4 & 44.1 \\
\hline GLP585 & 31.7 & 23.0 & 69.7 & 41.4 \\
\hline KATB9 & 67.0 & 72.1 & 60.2 & 66.4 \\
\hline Mean & 41.3 & 38.4 & 60.4 & 46.8 \\
\hline $\mathrm{CV}(\%)$ & 22.7 & & & \\
\hline \multicolumn{5}{|c|}{$\mathrm{LSD}_{0.05}:$ Line $=8.5$, Site $=3.0$, Line $x$ site $=14.7$} \\
\hline
\end{tabular}

$\mathrm{CV}=$ coefficient of variation $\mathrm{LSD}=$ least significant difference at $\mathrm{P}$-value threshold of 0.05

of the small red bean lines across three locations in Kenya. Most of the variability was explained by the 2 PCs $(96.9 \%)$. PC 1 contributed the most to that variability $(89.4 \%)$. Tigoni site, at high altitude, was the best environment for most of the genotypes. SR3 (KMA13-23-14) and SR5 (KMA13-25-09) were best for both Kabete and Tigoni sites; while SR9 (KMA13-30-16) was suited to Mwea. From the GGE biplot, Tigoni site was the most discriminative, being the farthest from the origin of the biplot graph. All genotypes inside the polygon, mainly those located close to the plot origin were less responsive than the vertex genotypes and not the best in any environment.

Pearson's correlation analyses. Pearson's correlation analyses showed that grain yield was positively correlated with days to flowering $\left(\mathrm{r}=0.66^{* * *}\right)$, days to maturity $(\mathrm{r}=0.74 * * *)$, growth habit $(\mathrm{r}=0.33 * * *)$, number of pods plant ${ }^{-1}\left(\mathrm{r}=0.85^{* * *}\right)$, number of seeds $\operatorname{pod}^{-1}(\mathrm{r}=0.26 * * *), 100$-seed mass $(\mathrm{r}=0.39 * * *)$ and harvest index $(\mathrm{r}=0.47 * * *)$. It was, however, negatively correlated with seedling emergence rate $(\mathrm{r}=-0.40 * * *)$ and plant vigour $(\mathrm{r}=-0.66 * * *)$. The number of pods 
TABLE 11. AMMI mean squares for seed yield $\left(\mathrm{kg} \mathrm{ha}^{-1}\right)$

\begin{tabular}{lrlrr}
\hline Source of variation & df & MS & CTV (\%) & CGxE (\%) \\
\hline Total & 287 & 3097461 & & \\
Treatments (G, E, G x E) & 71 & $10002229 * * *$ & 79.9 & \\
Genotypes (G) & 23 & $5438645^{* * *}$ & 17.6 & \\
Environments (E) & 2 & $241460323^{* * *}$ & 68.0 & \\
Interactions (G x E) & 46 & $2220626^{* * *}$ & 14.4 & \\
IPCA1 & 24 & $3785111^{* * *}$ & 10.2 & 88.9 \\
IPCA2 & 22 & $513916^{\text {ns }}$ & 1.3 & 11.1 \\
Replications & 9 & $10229384^{\mathrm{ns}}$ & 10.3 & \\
Error & 205 & 423163 & & \\
& & & & \\
CV $(\%)$ & 39.8 & & & \\
\end{tabular}

ns, $* * *$ and $* * *=$ no significant, significant, highly significant and very highly significant at P-value thresholds of $\mathrm{P}>0.05,<0.05,<0.01$ and $<0.001$, respectively; $\mathrm{df}=$ degree of freedom; IPCA1 and IPCA2 $=$ interaction principal component one and two, respectively; $\mathrm{MS}=$ mean squares; CTV $(\%)=$ percent of contribution to the total variation; $\mathrm{CGxE}(\%)=$ percent of the contribution to the $\mathrm{G} \times \mathrm{E}$ interaction; $\mathrm{CV}=$ coefficient of variation

plant $^{-1}$ was the most positively correlated with grain yield (Table 13).

Reaction to diseases. There were no significant differences $(\mathrm{P}>0.05)$ in the reaction of study genotypes to infection by target diseases in the field conditions (Table 14). The disease severity score was low to intermediate for angular leaf spot (1.0 to 3.5), anthracnose (1.0 to 3.1$)$, root rot (1.0 to 4.2$)$, bean common mosaic virus (1.0 to 2.2$)$ and common bacterial blight (1.0 to 5.5$)$. The prevailing relatively dry conditions in low altitude were not conducive to pathogens' development at the Mwea site.

\section{DISCUSSION}

Yield stability. The effects due to the interaction between the sites and the genotypes were significant (Table 11), implying that the performance of the newly developed small red bean lines varied with sites. The better performance recorded in high altitude (Tigoni site) could be due to relatively cooler conditions $\left(15.8^{\circ} \mathrm{C}\right)$ as well as a relatively well-distributed rainfall $(506 \mathrm{~mm})$ offered to crops. These led to slower plant growth and delayed maturity; and therefore, favoured high seed yield as previously reported by Singh et al. (2002).

Lower yields recorded at the low altitude (Mwea site) could be attributed to dry spells and erratic rainfall observed in that site during the experiment. The mean monthly temperature at this site was $24.3^{\circ} \mathrm{C}$, with a total rainfall of approximately $311.4 \mathrm{~mm}$ for the period of September 2017 to February 2018. In addition, more than $85 \%$ of that rainfall was recorded for October and November, leading to flooding of young seedlings. The most critical growth phases (flowering and podding) experienced a dry period as no rain was recorded in January and February 2018 (0 mm), and thus affected negatively the flowering, pod filling and the harvest index leading to lower grain yields.

These results were in agreement with those of Thung and Rao (1999), who demonstrated that changes detected in bean seed yield are mostly due to differences in rainfall pattern and temperature during the reproductive period. Several research reports support the observation that erratic rainfall may lead to 
TABLE 12. Seed yield $\left(\mathrm{kg} \mathrm{ha}^{-1}\right)$ of small red bean lines and locations in Kenya ranked (in parenthesis) by AMMI model, their IPCA scores and AMMI stability value (ASV)

\begin{tabular}{|c|c|c|c|c|c|c|c|c|}
\hline \multirow[t]{2}{*}{ Code } & \multirow[t]{2}{*}{ Genotype } & \multicolumn{3}{|c|}{ Environments } & \multirow{2}{*}{$\begin{array}{c}\text { Genotype } \\
\text { mean }\end{array}$} & \multirow[t]{2}{*}{$\operatorname{IPCAg}[1]$ Score } & \multirow[t]{2}{*}{ IPCAg[2]Score } & \multirow[t]{2}{*}{ ASV } \\
\hline & & Kabete & Mwea & Tigoni & & & & \\
\hline SR1 & KMA13-22-27 & 702 & 399 & 5,096 & $2,066(12)$ & -20.9 & 7.6 & 23.2 \\
\hline $\mathrm{SR} 2$ & KMA13-22-29 & 784 & 648 & 2,960 & $1,464(17)$ & 6.0 & 0.0 & 6.2 \\
\hline SR3 & KMA13-23-14 & 1,203 & 1,779 & 6,083 & $3,022(2)$ & -22.4 & -7.4 & 24.6 \\
\hline SR4 & KMA13-23-21 & 1,090 & 1,440 & 3,358 & $1,963(14)$ & 7.2 & -8.6 & 11.5 \\
\hline SR5 & KMA13-25-09 & 1,362 & 1,984 & 6,810 & $3,385(1)$ & -28.9 & -7.1 & 31.0 \\
\hline SR6 & KMA13-28-13 & 863 & 515 & 2,636 & $1,338(19)$ & 9.7 & 3.0 & 10.6 \\
\hline SR7 & KMA13-30-02 & 851 & 706 & 3,506 & $1,688(15)$ & 0.3 & 1.2 & 1.2 \\
\hline SR8 & KMA13-30-14 & 1,364 & 905 & 6,090 & $2,787(4)$ & -25.6 & 11.1 & 29.0 \\
\hline SR9 & KMA13-30-16 & 1,553 & 2,267 & 4,199 & $2,673(5)$ & 4.6 & -14.5 & 15.2 \\
\hline SR10 & KMA13-31-01 & 961 & 1,497 & 3,975 & $2,144(11)$ & -0.6 & -10.5 & 10.5 \\
\hline SR11 & KMA13-30-30 & 849 & 604 & 1,579 & $1,011(23)$ & 22.5 & -0.9 & 23.5 \\
\hline SR12 & KMA13-31-03 & 943 & 709 & 2,151 & $1,268(20)$ & 16.9 & -0.2 & 17.7 \\
\hline SR13 & KMA13-31-04 & 906 & 1,354 & 3,679 & $1,980(13)$ & 1.8 & -9.4 & 9.6 \\
\hline SR14 & KMA13-31-05 & 1,092 & 1,525 & 4,320 & $2,312(7)$ & -3.7 & -8.2 & 9.0 \\
\hline SR15 & KMA13-31-06 & 1,100 & 1,206 & 4,340 & $2,215(8)$ & -5.4 & -2.2 & 6.0 \\
\hline SR16 & KMA13-31-08 & 1,050 & 806 & 2,279 & $1,378(18)$ & 16.6 & 0.0 & 17.4 \\
\hline SR17 & KMA13-31-09 & 1,125 & 477 & 2,176 & $1,259(21)$ & 16.7 & 7.0 & 18.9 \\
\hline SR18 & KMA13-32-26 & 661 & 155 & 2,200 & $1,005(24)$ & 11.7 & 5.4 & 13.4 \\
\hline SR19 & KMA13-32-28 & 1,049 & 1,702 & 4,607 & $2,453(6)$ & -6.5 & -11.5 & 13.4 \\
\hline SR20* & KATB9 ${ }^{\mathrm{M}}$ & 1,431 & 601 & 2,902 & $1,645(16)$ & 10.9 & 11.2 & 16.0 \\
\hline $\mathrm{SR} 21 *$ & RWR719M & 701 & 505 & 2,193 & $1,133(22)$ & 13.7 & -0.3 & 14.4 \\
\hline SR22* & GLP585M $^{\mathrm{M}}$ & 1,079 & 859 & 4,676 & $2,205(9)$ & -11.2 & 4.5 & 12.5 \\
\hline SR23* & $\mathrm{G} 10909^{\mathrm{M}}$ & 1,744 & 597 & 4,187 & $2,176(10)$ & -2.1 & 18.9 & 19.1 \\
\hline
\end{tabular}


serious bean yield losses, if the stress occurs during the early vegetative growth (White and Singh, 1991; Mwale et al., 2009), as it was the case in Mwea where heavy rains flooded young seedlings. These losses could reach $50 \%$, if water stress is recorded in early pod filling (White and Singh, 1991; Blair et al., 2012; Assefa et al., 2017; Rao et al., 2017). This made us believe that the double water stress experienced by the bean crop in low altitude Mwea site explains the poor yield performance observed, regardless of the genetic background of test lines.

Another key reason for the observed poor performance was that most of test bean lines were of indeterminate growth habit. Mwale et al. (2009) reported that the effect of water stress was more pronounced for climbing cultivars than for dwarf counterparts, in a multi-environment trial conducted in Malawi. Indeterminate growth habit cultivars from this breeding programme should, therefore, be recommended to the high altitude environments of Kenya, which continue experiencing reliable and well-distributed rains. A similar observation was made by Singh (1989) in South America, where humid high altitude conditions were more conducive to climbing bean cultivars.

From the AMMI ANOVA (Table 11), the environment was responsible for the largest part of observed variability $(68 \%)$. Although the environment is a broad term and includes many factors (predictable and unpredictable), it was temperature and amount and distribution of rainfall that mainly contributed to observed variability. Kabete experienced mean monthly temperatures of $18.2^{\circ} \mathrm{C}$ and an amount of rainfall of $372 \mathrm{~mm}$. Mwea in low altitude was warmer $\left(24{ }^{\circ} \mathrm{C}\right)$, with erratic rainfall as described previously $(311 \mathrm{~mm})$; while Tigoni in high altitude experienced cooler conditions $\left(15.8^{\circ} \mathrm{C}\right)$ with a relatively well-distributed rainfall along the growing season $(506 \mathrm{~mm})$. Other key environmental factors (e.g. soil type, nutrients and $\mathrm{pH}$ ) were not significantly different among the three sites as described for the experimental site. 


\section{Scatter plot (Total - $96.86 \%$}

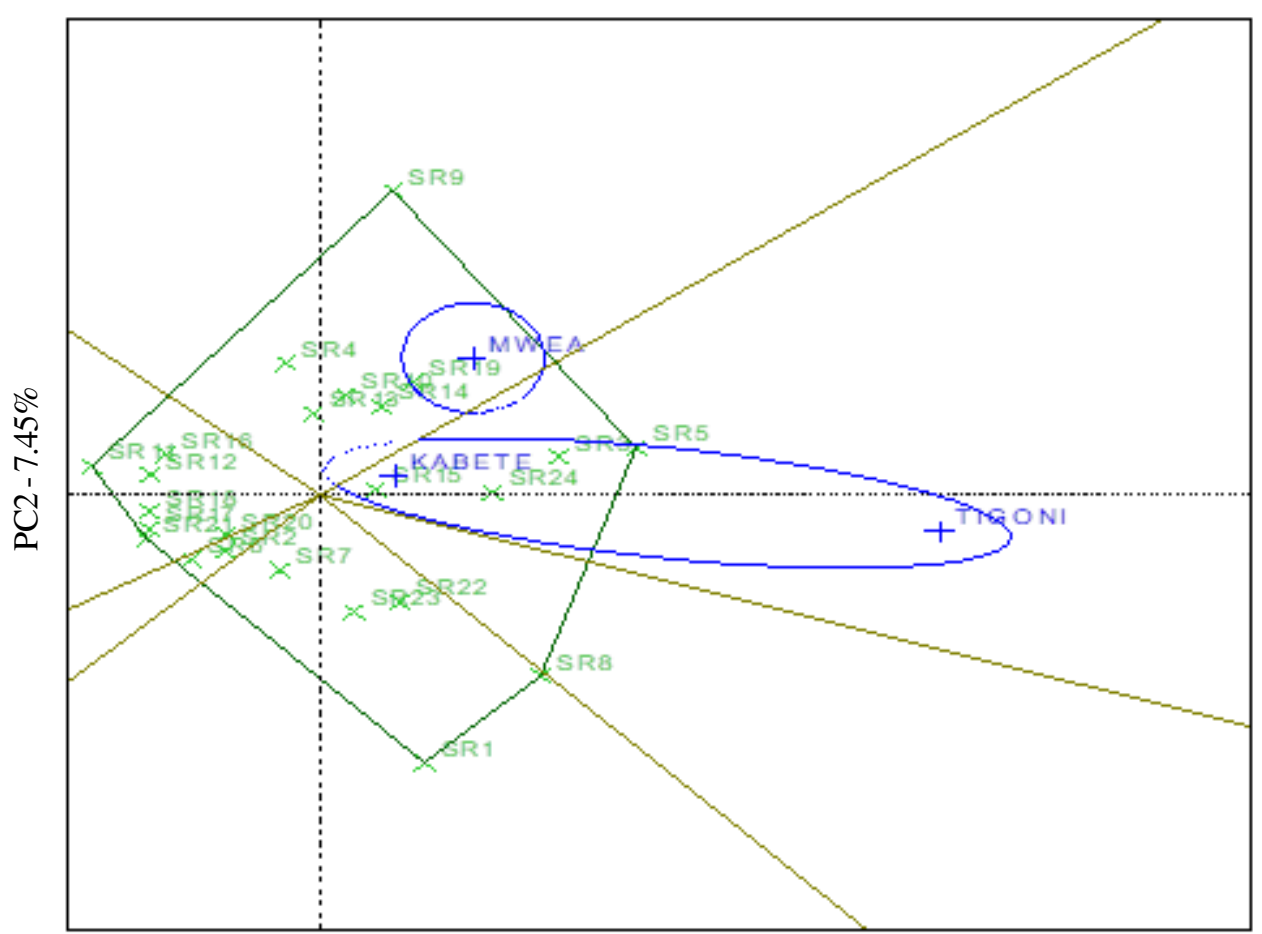

PC1 $-89.41 \%$

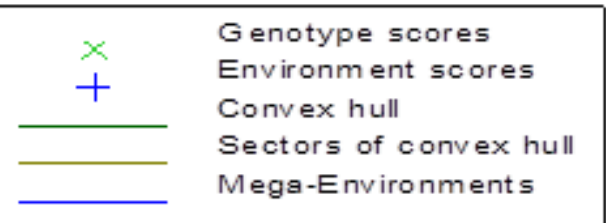

Figure 1. Polygon view of GGE biplot for best small red bean genotypes for seed yield across three environments in Kenya.

From AMMI stability value, higher yielding lines were also the most unstable across sites of the present study. This showed that small red bean lines with high genotypic yield potential were very responsive to environmental factors, such as rainfall and temperatures. Thus, any improvement in environmental conditions led to significant yield increase. Similar observations were reported on small red bean lines in Ethiopia by Tadesse et al. (2017). Lin et al. (1986) demonstrated that a satisfactory Type I stability parameter (i.e. CV) is often linked with reduced yield performance.

Correlations between seed yield and yield related parameters. A significant positive correlation was recorded between seed yield and yield related parameters, except for plant vigour score and seedling emergence rate (Table 13). The number of pods per plant was the most strongly correlated to grain yield, suggesting that it can be used by breeders as an indirect selection method for grain yield. 
High yielding lines were late flowering and maturing as they contained a large number of flowers and pods, which appeared progressively. As the highest number of pods was recorded on climbing genotypes, there was a strong correlation between growth habit with duration to flowering and to maturity, confirming the general assumption that climbers take longer to flower and mature compared to bush bean lines (Welsh et al., 1995).

The correlation was also significant between the growth habit and the seed yield; climbing genotypes yielded higher than bush beans. In addition to the ability of bearing more pods per plant, which allows climbing genotypes to achieve enormously higher yields than bush bean counterparts, Mekbib (2003) noted that climbing genotypes possess a yield compensation capacity to recover rapidly from stress.

Results also showed a positive correlation between seed yield and seed size, such that higher seed yields were recorded on genotypes with higher 100-seed mass. In water stressed environments, growing larger seeds improves early-season plant growth, which is advantageous for crop establishment and vigour (Lima et al., 2005). Vigorous plants bore more pods, and thus led to higher yields as was observed in the Pearson's correlation (Table 13).

Reaction to target pathogens. Dry conditions during the study period were not conducive to pathogens' development. Disease severity depended mostly on environmental effects than the genetic background of test small red bean lines (Table 14). Disease symptoms were almost absent from bean crops grown at the low altitude Mwea site, as it was the driest site during the study period. Although symptoms of target pathogens occurred in medium and high altitudes, recorded disease severity was very low. However, the absence of symptoms on test lines were not enough to conclude that the small red bean lines were resistant to target 
TABLE 14. Reaction to target diseases of small red $\mathrm{F}_{1.7}$ bean lines grown at various locations in Kenya

\begin{tabular}{|c|c|c|c|c|c|c|c|c|c|c|c|c|c|c|c|}
\hline \multirow[t]{2}{*}{ Line } & \multicolumn{3}{|c|}{ ALS } & \multicolumn{3}{|c|}{ ANTH } & \multicolumn{3}{|c|}{$\mathrm{CBB}$} & \multicolumn{3}{|c|}{ RR } & \multicolumn{3}{|c|}{ BCMV } \\
\hline & Kabete & Mwea & Tigoni & Kabete & Mwea & Tigoni & Kabete & Mwea & Tigoni & Kabete & Mwea & Tigoni & Kabete & Mwea & Tigoni \\
\hline KMA13-22-27 & 1.9 & 1.0 & 1.2 & 2.3 & 1.0 & 2.2 & 5.5 & 1.0 & 2.0 & 1.0 & 1.0 & 3.0 & 1.0 & 1.0 & 1.2 \\
\hline KMA13-22-29 & 2.1 & 1.3 & 1.5 & 1.0 & 1.0 & 1.5 & 2.0 & 1.0 & 4.4 & 1.0 & 1.0 & 3.0 & 1.3 & 1.0 & 1.1 \\
\hline KMA13-23-14 & 1.0 & 1.0 & 2.0 & 1.0 & 1.0 & 1.0 & 2.9 & 1.0 & 3.0 & 3.4 & 1.0 & 2.0 & 1.7 & 1.0 & 2.0 \\
\hline KMA13-23-21 & 2.0 & 1.0 & 3.0 & 2.0 & 1.0 & 3.0 & 1.0 & 1.0 & 3.0 & 3.0 & 1.0 & 3.0 & 1.0 & 1.0 & 1.5 \\
\hline KMA13-25-09 & 1.0 & 1.0 & 1.3 & 1.4 & 1.0 & 2.0 & 4.4 & 1.3 & 3.5 & 1.0 & 1.0 & 3.5 & 1.2 & 1.0 & 1.0 \\
\hline KMA13-28-13 & 2.0 & 1.0 & 1.5 & 1.8 & 1.0 & 1.0 & 3.1 & 1.0 & 3.0 & 4.2 & 1.0 & 3.0 & 1.1 & 1.0 & 1.0 \\
\hline KMA13-30-02 & 2.0 & 1.1 & 3.5 & 2.0 & 1.0 & 1.0 & 3.0 & 1.1 & 4.0 & 2.0 & 1.0 & 3.0 & 1.0 & 1.0 & 1.0 \\
\hline KMA13-30-14 & 2.0 & 1.0 & 2.0 & 2.0 & 1.0 & 1.7 & 2.0 & 1.0 & 4.0 & 1.0 & 1.0 & 3.3 & 1.0 & 1.0 & 1.2 \\
\hline KMA13-30-16 & 2.2 & 1.0 & 2.4 & 1.2 & 1.0 & 2.0 & 2.0 & 1.0 & 1.9 & 3.5 & 1.0 & 3.0 & 1.1 & 1.0 & 1.6 \\
\hline KMA13-30-30 & 2.0 & 1.1 & 2.0 & 1.0 & 1.0 & 2.0 & 2.0 & 1.1 & 2.8 & 2.0 & 1.0 & 2.8 & 1.1 & 1.0 & 1.0 \\
\hline KMA13-31-01 & 2.0 & 1.0 & 2.0 & 2.1 & 1.0 & 1.0 & 2.0 & 1.0 & 2.0 & 4.0 & 1.0 & 3.3 & 1.4 & 1.0 & 2.2 \\
\hline KMA13-31-03 & 2.0 & 1.0 & 1.0 & 1.0 & 1.0 & 1.0 & 1.5 & 1.0 & 2.0 & 4.0 & 1.0 & 3.1 & 1.0 & 1.0 & 1.4 \\
\hline KMA13-31-04 & 1.0 & 1.0 & 1.0 & 3.1 & 1.0 & 2.0 & 2.0 & 1.0 & 2.5 & 3.1 & 1.0 & 3.0 & 1.0 & 1.0 & 1.0 \\
\hline KMA13-31-05 & 1.9 & 1.5 & 2.0 & 1.0 & 1.0 & 1.2 & 2.5 & 1.5 & 3.0 & 1.0 & 1.0 & 3.0 & 1.3 & 1.0 & 1.0 \\
\hline KMA13-31-06 & 2.0 & 1.0 & 1.0 & 1.3 & 1.0 & 1.0 & 2.0 & 1.0 & 3.0 & 3.3 & 1.0 & 3.0 & 1.7 & 1.0 & 1.0 \\
\hline KMA13-31-08 & 2.0 & 1.0 & 2.0 & 2.0 & 1.0 & 1.0 & 2.9 & 1.0 & 3.0 & 3.0 & 1.0 & 3.0 & 1.0 & 1.0 & 1.2 \\
\hline KMA13-31-09 & 1.7 & 1.3 & 2.0 & 2.0 & 1.0 & 2.5 & 1.0 & 1.3 & 3.0 & 1.0 & 1.0 & 3.5 & 1.2 & 1.0 & 1.6 \\
\hline KMA13-32-26 & 1.0 & 1.0 & 2.0 & 2.0 & 1.0 & 1.0 & 4.4 & 1.6 & 3.0 & 1.0 & 1.0 & 3.0 & 1.1 & 1.0 & 1.0 \\
\hline KMA13-32-28 & 1.5 & 1.2 & 1.0 & 1.0 & 1.0 & 1.3 & 3.1 & 1.2 & 2.0 & 3.4 & 1.0 & 3.0 & 1.0 & 1.0 & 2.2 \\
\hline G10909 & 2.0 & 1.3 & 2.0 & 1.3 & 1.0 & 2.0 & 3.0 & 1.3 & 2.0 & 3.0 & 1.0 & 3.3 & 1.0 & 1.0 & 1.4 \\
\hline G2333 & 1.8 & 1.0 & 1.0 & 1.3 & 1.0 & 2.0 & 2.0 & 1.0 & 2.0 & 1.0 & 1.0 & 3.0 & 1.1 & 1.0 & 2.0 \\
\hline GLP585 & 2.1 & 1.0 & 2.0 & 2.1 & 1.0 & 2.0 & 2.0 & 1.0 & 2.0 & 4.2 & 1.0 & 2.8 & 1.1 & 1.0 & 1.5 \\
\hline KATB9 & 2.0 & 1.6 & 2.0 & 2.0 & 1.0 & 1.0 & 2.0 & 1.0 & 1.5 & 2.0 & 1.0 & 3.3 & 1.4 & 1.0 & 1.0 \\
\hline
\end{tabular}


diseases, as most of the variability was attributed to environmental factors such as soil and air humidity and temperature. This study showed that field disease scoring (with dependence on natural epiphytotics) is not a reliable method to appreciate the genetic resistance as the influence of environment is very high. These results support findings by Nelson et al. (1991) that screening resistance under field conditions may lead to inconsistent conclusions compared to a greenhouse screening method.

In field screening, genotypic effects are confounded with environmental and other biotic effects, making it less reliable. Another major drawback of field disease resistance testing is that in some context as it was the case in this study, environmental conditions may not be conducive to disease development, making conclusions unreliable.

\section{ACKNOWLEDGMENT}

The financial support received from the Université Evangélique en Afrique (UEABukavu) for conducting this research, is gratefully acknowledged.

\section{REFERENCES}

Asfaw, A., Blair, M.W. and Almekinders, C. 2009. Genetic diversity and population structure of common bean (Phaseolus vulgaris $\mathrm{L}$.) landraces from the East African highlands. Theoretical and Applied Genetics 120(1):1-12.

Assefa, T., Rao, I.M., Cannon, S.B., Wu, J., Gutema, Z., Blair, M., Otyama, P., Alemayehu, F. and Dagne, B. 2017. Improving adaptation to drought stress in white pea bean (Phaseolus vulgaris L.): Genotypic effects on grain yield, yield components and pod harvest index. Plant Breeding 136(4):548-561.

Assefa, T., Wu, J., Beebe, S.E., Rao, I.M., Marcomin, D. and Rubyogo, J.C. 2015. Improving adaptation to drought stress in small red common bean: Phenotypic 
differences and predicted genotypic effects on grain yield, yield components and harvest index. Euphytica 203(3):477-489.

Beebe, S.E. 2012. Common bean breeding in the tropics. Plant Breeding Reviews 36:357-426.

Blair, M.W., Galeano, C.H., Tovar, E., Torres, M.C.M., Castrillón, A.V., Beebe, S.E. and Rao, I.M. 2012. Development of a Mesoamerican intra-gene pool genetic map for quantitative trait loci detection in a drought tolerant $\times$ susceptible common bean (Phaseolus vulgaris L.) cross. Molecular Breeding 29(1):71-88.

Borel, J.C., Ramalho, M.A.P., De Carvalho, V.R.F. and Abreu, A.F.B. 2013. Genetic and phenotypic parameters in common bean segregant populations from intra- and intergene pool crosses of elite lines. Euphytica 193:39-47.

Corrêa, A.M., Gonçalves, M.C. and Teodoro, P.E. 2016. Pattern analysis of multienvironment trials in common bean genotypes. Bioscience Journal 32(2):328336.

Corrêa, A.M., Lima, A.R.S., Braga, D.C., Ceccon, G., Teodoro, P.E., Silva Junior, A.C. and Silva, F.A. 2015. Agronomic performance and genetic variability among common bean genotypes in Savanna/ Pantanal Ecotone. Journal of Agronomy 14(3):175-179.

Gauch, G.H. and Zobel, R.W. 1997. Identifying mega-environments and targeting genotypes. Crop Science 37(2):311-326.

Gauch, H.G., Piepho, H.P. and Annicchiarico, P. 2008. Statistical analysis of yield trials by AMMI and GGE: Further considerations. Crop Science 48(3):866889.

Graham, R.D., Welch, R.M., Saunders, D.A., Ortiz-Monasterio, I., Bouis, H.E., Bonierbale, M., De Haan, S., Burgos, G., Thiele, G., Liria, R. and Meisner, C.A. 2007. Nutritious subsistence food systems. Advances in Agronomy 92:2-75.
Kimani, P.M., Buruchara, R., Ampofo, K., Pyndji, M., Chirwa, R. and Kirkby, R. 2005. Breeding beans for smallholder farmers in Eastern, Central and Southern Africa: Constraints, achievements and potential. In: Pan-African Bean Research Network (PABRA) Millennium Workshop, 28 May-1 June, Arusha, Tanzania. pp. 1128.

Liebenberg, A.J. 2002. Dry bean production. Printed and published by Department of Agriculture, Resource Centre, Directorate Agricultural Information Services, Private Bag X, 144, 27p.

Lima, E.R., Santiago, A.S., Araújo, A.P. and Teixeira, M.G. 2005. Effects of the size of sown seed on growth and yield of common bean cultivars of different seed sizes. Brazilian Journal of Plant Physiology 17(3):273-281.

Lin, C.S., Binns, M.R. and Lefkovitch, L.P. 1986. Stability analysis: where do we stand? Crop Science 26:894-900.

Mahuku, G.S., Henriquez, M.A., Montoya, C., Njara, C., Teran, H. and Beebe, S. 2011. Inheritance and development of molecular markers linked to angular leaf spot resistance genes in the common bean accession G10909. Molecular Breeding 28(1):57-71.

Mekbib, F. 2003. Yield stability in common bean (Phaseolus vulgaris L.) genotypes. Euphytica 130(2):147-153.

Mondo, J.M., Kimani, P.M. and Narla, R.D. 2019. Genotype $x$ environment interactions on seed yield of inter-racial common bean lines in Kenya. World Journal of Agricultural Research 7(3):76-87.

Mwale, V.M., Bokosi, J.M., Masangano, C.M., Kwapata, M.B., Kabambe, V.H. and Miles, C. 2009. Performance of climber common bean (Phaseolus vulgaris L.) lines under Researcher Designed Farmer Managed (RDFM) system in three bean agro-ecological zones of Malawi. African Journal of Biotechnology 8(11):24602468. 
Nelson, B.D., Helms, T.C. and Olson, M.A. 1991. Comparison of laboratory and field evaluations of resistance in soybean to Sclerotinia sclerotiorum. Plant Disease 75:662-665.

Njuguna, S.M. 2014. Marker assisted gamete selection for multiple disease resistance in Mesoamerican bean genotypes and race typing of angular leaf spot pathogen in Kenya. MSc. Thesis, University of Nairobi, Nairobi, Kenya. 223pp.

Okii, D., Mukankusi, C., Sebuliba, S., Tukamuhabwa, P., Tusiime, G., Talwana, H., Odong, T., Namayanja, A., Paparu, P., Nkalubo, S., Otim, M., Ugen, M., Buah, S. and Gepts, P. 2018. Genetic variation, heritability estimates and GXE effects on yield traits of Mesoamerican common bean (Phaseolus vulgaris L.) germplasm in Uganda. Plant Genetic Resources 16(3):237-248.

Okii, D., Tukamuhabwa, P., Odong, T., Namayanja, A., Mukabaranga, J., Paparu, P. and Gepts, P. 2014. Morphological diversity of tropical common bean germplasm. African Crop Science Journal 22(1):59-68.

Otsyula, R., Ajanga, S.I., Buruchara, R.A., Mahuku, G.S. and Rubaihayo, P. 2003. Inheritance and transfer of root rots (Pythium) resistance to bean genotypes. African Crop Science Conference Proceedings 6:295-298.

Purchase, J.L. 1997. Parametric analysis to describe genotype $x$ environment interaction and yield stability in winter wheat. Ph.D. Thesis. University of the Orange Free State, South Africa.

Rao, I.M., Beebe, S.E., Polania, J., Grajales, M., Cajiao, C., Ricaurte, J., García, R. and Rivera, M. 2017. Evidence for genotypic differences among elite lines of common bean in the ability to remobilize photosynthate to increase yield under drought. Journal of Agricultural Science 155(6):857-875.
Samonte, S.O.P., Wilson, L.T., McClung, A.M. and Medley, J.C. 2005. Targeting cultivars onto rice growing environments using AMMI and SREG GGE biplot analyses. Crop Science 45(6):2414-2424.

Schoonhoven, A.V. and Pastor-Corrales, M.A. 1987. Standard system for the evaluation of bean germplasm. CIAT, Cali, Colombia, 56.

Sichilima, T., Mapemba, L. and Tembo, G. 2016. Drivers of dry common beans trade in Lusaka, Zambia: A trader's perspective. Sustainable Agriculture Research 5(2):15.

Singh, S.P. 1989. Patterns of variation in cultivated common bean (Phaseolus vulgaris, Fabaceae). Economic Botany 43(1):39-57.

Singh, S.P. 1994. Gamete selection for simultaneous improvement of multiple traits in common bean. Crop Science 34(2):352-355.

Singh, S.P. and Schwartz, H.F. 2010. Breeding common bean for resistance to diseases: a review. Crop Science 50(6):2199-2223.

Singh, S.P., Teran, H., Muñoz, C.G. and Osorno, J.M. 2002. Selection for seed yield in Andean intra-gene pool and Andean $x$ Middle American inter-gene pool populations of common bean. Euphytica 127(3):437-444.

Tadesse, T., Tekalign, A., Mulugeta, B. and Sefera, G. 2017. Identification of stability and adaptability of small red bean cultivars using AMMI analysis. Plant 5(6):99-103.

Terán, H. and Singh, S.P. 2002. Comparison of sources and lines selected for drought resistance in common bean. Crop Science 42(1):64-70.

Thung, M. and Rao, I.M. 1999. Integrated management of abiotic stresses. In: S.P. Singh (Ed.), Common bean improvement in the twenty-first century, pp. 331-370. Kluwer Academic Publishers, The Netherlands. 
VSN International. 2012. GenStat for Windows, $15^{\text {th }}$ Edn. Hemel Hempstead: VSN International. Web page: GenStat.co.uk.

Wagara, I.M. and Kimani, P.M. 2007. Resistance of nutrient-rich bean varieties to major biotic constraints in Kenya. In African Crop Science Conference Proceedings 8:2087-2090.

Welsh, W., Bushuk, W., Roca, W. and Singh, S.P. 1995. Characterization of agronomic traits and markers of recombinant inbred lines from intra- and interracial populations of Phaseolus vulgaris L. Theoretical and Applied Genetics 91(1):169-177.

White, J.W. and Singh, S.P. 1991. Breeding for adaptation to drought. pp. 501-560. In: Schoonhoven, A.V. and Voysest, O. (Eds.). Common Beans: Research for Crop Improvement. C.A.B. International, CIAT, Cali, Colombia.

Wortmann, C.S., Kirkby, R.A., Elude, C.A. and Allen, D.J. 1998. Atlas of common bean (Phaseolus vulgaris L.) production in Africa. CIAT publication No.297. 133pp. 